\title{
Relevance of the exopolysaccharide of marine Pseudomonas sp. strain S9 for the attachment of Ciona intestinalis larvae
}

\author{
U. Szewzyk*, C. Holmström, M. Wrangstadh, M.-O. Samuelsson**, J. S. Maki***, \\ S. Kjelleberg ${ }^{*}$
}

University of Göteborg, Dept of General and Marine Microbiology, Carl Skottsbergs Gata 22, S-413 19 Göteborg, Sweden

\begin{abstract}
Effects of bacterial exopolymers on the attachment of larvae of the ascidian Ciona intestinalis were examined in the laboratory. A marine Pseudomonas sp. (strain S9) which forms and excretes a peripheral exopolysaccharide during energy and nutrient starvation was used as a test organism. The experiments also focused on inhibition of exopolymer excretion and the use of a transposon-generated mutant that was deficient in the release of peripheral exopolymer. Two modes of larval attachment to surfaces coated with bacteria could be distinguished, depending on the amount of peripheral exopolysaccharide present: active attachment by use of the adhesive organs, and passive attachment due to trapping of the larvae in the exopolymer material. All larvae underwent metamorphosis and could therefore contribute to population recruitment. A similar increase in the extent of attachment in the presence of peripheral exopolysaccharide could be observed for both fertilized and non-fertilized eggs. Our findings show that exopolymers produced by bacteria may increase the extent of attachment of $C$. intestinalis larvae.
\end{abstract}

\section{INTRODUCTION}

The processes that control biofouling of surfaces in marine environments are poorly understood. Because several factors are involved in biofilm formation, such as development of a conditioning film, attachment of bacteria, algae and macrofouling organisms, and their subsequent growth (Bryers \& Characklis 1982), biofouling studies may be performed at different levels. One line of research is to examine the interaction of bacteria or macrofouling organisms with the conditioning film. These interactions are mainly relevant for the colonization of newly exposed, 'clean' surfaces. Another line of research is to study the interaction of already existing biofilms, composed mainly of bacteria and algae, with macrofouling organisms. This type of interaction is

Present addresses:

- Statens Bakteriologiska Laboratorium (SBL), S-105 21 Stockholm, Sweden

- IVL, Box 21060, S-100 31 Stockholm, Sweden

-.. Laboratory of Microbial Ecology, Division of Applied Sciences, Harvard University, Cambridge, Massachusetts 02138, USA

${ }^{\dagger}$ Author for correspondence relevant for the further colonization of surfaces which are already covered by a biofilm.

Many macrofouling organisms develop a free-living larval stage, which makes it possible for the larvae to disperse, find suitable surfaces, and subsequently attach to them. The interaction between invertebrate larvae and inanimate surfaces has been extensively studied (Barnes 1956, Crisp 1974, Eiben 1976, Butman et al. 1988). ZoBell \& Allen (1935) indicated that marine bacterial films influenced settlement of invertebrate larvae; early studies also proposed that slime films of bacteria, due to extracellular polymeric substances, might act as an adhesive layer for the larvae (ZoBell 1938). Since these studies, relatively little attention has been paid to the role of extracellular polysaccharides in larval attachment (Maki et al. 1988, Maki et al. 1989). However, the influence of specific factors excreted by bacteria and other organisms on larval attachment and metamorphosis has received more interest (Morse et al. 1979, Kirchman et al. 1982a, b, Rittschof et al. 1986a, b). The aim of the present study was to examine the relevance of bacterial exopolymers for the attachment of larvae of the ascidian Ciona intestinalis. As a model bacterial slime-former we used Pseudomonas sp. S9. 
This marine strain is particularly suitable as a test organism for the attachment of larvae because the production and release of exopolysaccharide (Wrangstadh et al. 1986), and the regulation of its formation (Wrangstadh et al. 1990), are well characterized. The strain produces an integral, capsule-like form of the exopolysaccharide during growth and a peripheral (loosely associated with the cell wall) form during substrate limitation. The exopolysaccharide contains $<1 \%$ proteins and lipids (Wrangstadh et al. 1986). The peripheral exopolysaccharide released by Pseudomonas sp. S9 forms a dense slime layer on surfaces. By using a transposon-generated mutant of strain S9, which has been shown to produce only the integral type of the exopolysaccharide, it was possible to study the effects of the bacterial film on larval attachment in the absence of slime-layer formation.

For clarity, the term larval attachment is used for the description of surface-associated larvae, i.e. those that are attached by the adhesive papillae and those that are trapped by the bacterial slime layer. The term larval settlement refers to the process of larval recruitment to a surface.

\section{MATERIALS AND METHODS}

Preparation of larvae. Adult Ciona intestinalis were collected from June to September in the Gullmarsfjord at the Swedish west coast at a depth of 25 to $28 \mathrm{~m}$. Water temperature at this depth was ca $14^{\circ} \mathrm{C}$. Larvae were prepared by mixing eggs and sperm from different specimens in filtered aerated seawater for $2 \mathrm{~h}$ at $14^{\circ} \mathrm{C}$. After fertilization, the excess sperm were washed away and the fertilized eggs were incubated on a shaker at $14^{\circ} \mathrm{C}$ until the larvae hatched. The hatching took ca $36 \mathrm{~h}$, and the water was changed at least 5 times during this period. Two hours after onset of hatching, larvae were collected and concentrated to a final density of 8 to 12 larvae $\mathrm{ml}^{-1}$ filtered seawater.

Bacteria. Pseudomonas sp. S9 or the transposongenerated mutant B29 (Wrangstadh et al. 1990) were grown in VNSS-medium (Mårdén et al. 1985) to stationary phase. For starvation experiments, the cells were washed twice in a nine salt solution (NSS; Mårdén et al. 1985) and resuspended in NSS to a final optical density (OD) of 0.1 at $610 \mathrm{~nm}$ (= starvation cell suspension).

Non-biotic surfaces. Hydrophobic (Cerbo) and hydrophilic (Nunc) polystyrene Petri dishes were used as non-biotic test surfaces. Air bubble contact angles (e.g. Maki et al. 1989) of these 2 substrata were measured to be $90^{\circ}$ and $28^{\circ}$, respectively. These experiments were included to select a control surface, in order to ascertain that the larvae attached to the same degree in experiments involving different larval batches.

Cell layers and growing biofilms. To prepare cell layers of starved S9 or B29 cells on various surfaces, $20 \mathrm{ml}$ of a starvation cell suspension in NSS were transferred to Petri dishes and incubated for $24 \mathrm{~h}$. The supernatant was removed and the cell layer on the bottom of the dish was washed twice with $20 \mathrm{ml}$ NSS. Cell layers of various thickness were obtained by varying the number of cells in the starvation suspensions. A cell suspension with an $\mathrm{OD}_{610}$ of 0.1 after $24 \mathrm{~h}$ of starvation resulted in a monolayer, while one with an $O D_{610}$ of 1.0 resulted in the formation of a thick multilayer.

In some experiments, growing biofilms of S9 or B29 were used. These films were produced in the following way: $20 \mathrm{ml}$ of the growth medium (VNSS) were transferred to Petri dishes and inoculated with $0.1 \mathrm{ml}$ of a $\log$ phase culture of either S9 or B29. After 24 h, the supernatant was poured off and the biofilm on the dish was washed 3 times with $20 \mathrm{ml}$ of NSS before being used in the larval settlement and attachment assays.

Starvation supernatant. After 24 h of starvation, cell suspensions of S9 were centrifuged $(10000 \times g$, $30 \mathrm{~min}$ ) and the supernatant was used directly in attachment assays (see below).

Attachment assay with Ciona intestinalis larvae. Aliquots of larval suspension $(20 \mathrm{ml})$ were transferred to each of the prepared Petri dishes and incubated for $24 \mathrm{~h}$ in the dark at $25^{\circ} \mathrm{C}$. For experiments with the bacterial starvation supernatant, $10 \mathrm{ml}$ of the supernatant were mixed with $10 \mathrm{ml}$ of a larval suspension (15 to 20 larvae $\mathrm{ml}^{-1}$ ) in a Petri dish and incubated as described above. By the end of the incubation time, the larvae were counted under a stereomicroscope and separated into 3 groups: (1) attached by the adhesive papillae located at the anterior end of the trunk ('attached'); (2) attached by other body parts or trapped in the polymer ('trapped'); (3) non-attached. The larvae of groups 1 and 2 together constituted surface-associated larvae. All experiments were performed at least twice, with 3 parallel tests for each experiment. Statistical analysis for an evaluation of differences between various treatment was performed using a form of $t$-test where unequal variances in the samples were considered.

Inhibition of peripheral exopolysaccharide formation by chloramphenicol. Chloramphenicol inhibits formation and release of a peripheral form of the exopolysaccharide during starvation (Wrangstadh et al. 1990). Chloramphenicol was added to the starvation suspension at a final concentration of $100 \mathrm{~g} \mathrm{ml}^{-1}$ at different times during starvation. After addition, the inhibitor was present until the end of each experiment. At time zero of starvation, chloramphenicol was added to the bacterial culture immediately before the cen- 
trifugation and washing steps. Control experiments revealed that the larvae were not affected by the addition of chloramphenicol.

\section{RESULTS}

\section{Larval attachment on non-biotic surfaces}

Ciona intestinalis larvae attached to both hydrophilic and hydrophobic non-biotic surfaces-but with different kinetics - and subsequently underwent metamorphosis. The most rapid attachment occurred on hydrophobic Petri dishes and reached a saturation value of about 70 to $90 \%$ of larvae attached after 5 to $10 \mathrm{~h}$ (Fig. 1). The rate of attachment on the hydrophilic Petri dishes was slower, and the degree of attachment (percentage of larvae attached) reached a saturation value of about $40 \%$ after $10 \mathrm{~h}$ (Fig. 1). Larval attachment was significantly greater $(p>0.003)$ on the hydrophobic dishes at all sampling times. All larvae associated with the clean plastic surfaces were attached by the adhesive papillae,

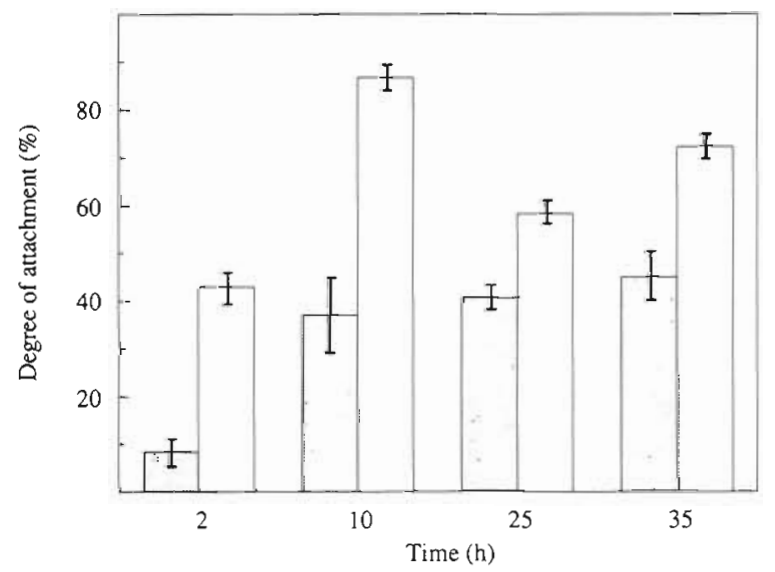

Fig. 1. Ciona intestinalis. Attachment of larvae over time on a hydrophilic (shaded bars) and a hydrophobic (open bars) Petri dish. Values represent number of attached (by the adhesive papillae) larvae and are calculated as the degree of attachment $=100 \times$ (number of adhering larvae)/(total number of larvae added to the system). Values are mean $\pm \mathrm{SD}$

located at the anterior end of the trunk. All surfaceassociated, as well as most of the non-attached larvae, subsequently underwent metamorphosis.

\section{Attachment of fertilized eggs, non-fertilized eggs and larvae}

Non-fertilized eggs, fertilized eggs, and larvae of Ciona intestinalis were tested for attachment to hydro- phobic surfaces and to bacterial cell layers of Pseudomonas sp. S9. As shown in Fig. 2, a low percentage of non-fertilized eggs attached to the clean hydrophobic dish. The presence of a bacterial cell layer significantly increased the attachment of both fertilized $(p<0.009)$ and non-fertilized $(p<0.002)$ eggs, while the starvation supernatant significantly increased the attachment of only the non-fertilized eggs $(p<0.008)$. The attachment of larvae to the bacterial surface

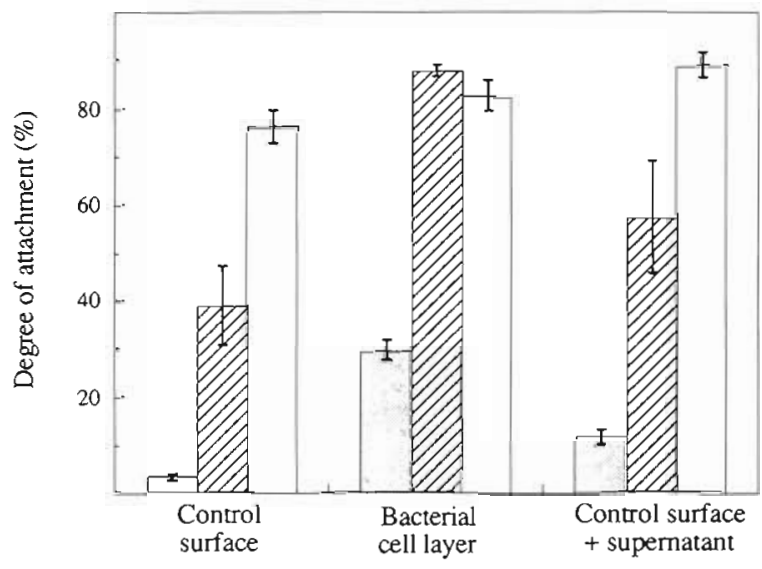

Fig. 2. Ciona intestinalis. Comparison of attachment of nonfertilized eggs (shaded bars), fertilized eggs (hatched bars), and larvae (open bars) to a hydrophobic Petri dish (Control), a Pseudomonas sp. $\$ 9$ cell layers, and the control surface in the presence of $\mathrm{S} 9$ starvation supernatant. Values calculated as in Fig. 1

(Fig. 2) involved both attached (attached by adhesive papillae) and surface-associated (attached plus trapped) larvae. This distinction was made because not all larvae that were associated with the $\$ 9$ cell layer had attached by their adhesive organs; many were trapped by their tail or other body parts. The fertilized eggs displayed a much greater degree of attachment to the hydrophobic dish and to the bacterial layer compared to the non-fertilized eggs.

A greater attachment of larvae compared to that of fertilized and non-fertilized eggs was observed for the control surface $(p<0.009)$, and in the presence of supernatant $(p<0.04)$. The attachment of larvae and fertilized eggs to the bacterial cell surface was the same.

\section{Larval attachment on thin bacterial layers}

Larval attachment to hydrophobic surfaces covered with layers of $24 \mathrm{~h}$ starved cells of either the exopolysaccharide-producing Pseudomonas sp. S9 or the transposon-generated mutant B29 (deficient in release of peripheral exopolysaccharide) was evaluated for the time-course experiments. Exopolysac- 
charides remained on the substrata after the supernatant was removed from the dish and the cell layer washed twice with NSS. The data in Fig. 3 represent both attached and surface-associated larvae. In experiments with cell layers of the mutant B29, the number of attached larvae was initially higher than, and after ca $25 \mathrm{~h}$ about the same as, that in the experiments with S9 layers. As the percentage of sur-

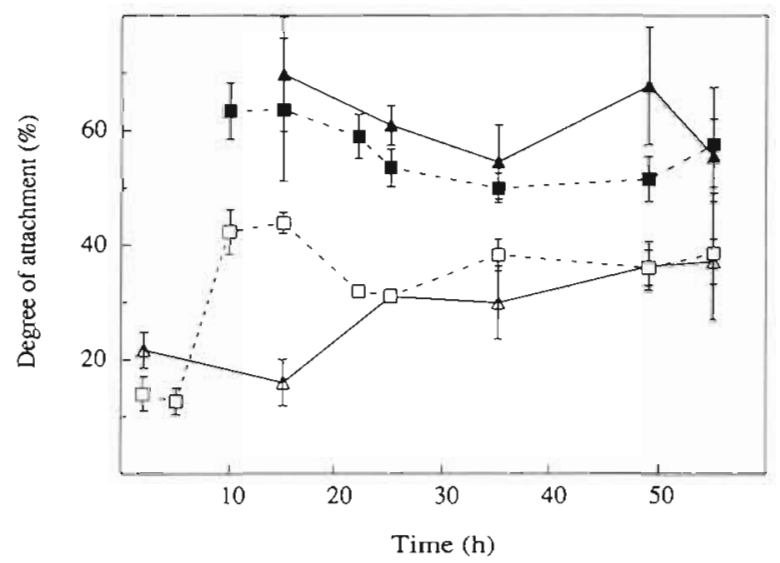

Fig. 3. Ciona intestinalis. Time course of larval attachment on cell layers of $(\Delta, \Delta)$ Pseudomonas sp. S9 or $(\mathbf{\bullet}, \square)$ the mutant B29 strain. Filled symbols: surface-associated larvae [both attached (by the adhesive papillae) and trapped]; open symbols: attached larvae. Values calculated as in Fig. 1

face-associated larvae appeared to be somewhat lower on the B29 than on the S9 surface, the number of trapped larvae was lower.

\section{Inhibition of peripheral exopolysaccharide formation by chloramphenicol}

Chloramphenicol was added to the starvation suspension of Pseudomonas sp. S9 cells at different times during starvation. After a total starvation time of $24 \mathrm{~h}$, the effect of bacterial cell layers on larval attachment was examined. The addition of chloramphenicol at the onset of starvation resulted in a significant decrease in larval attachment on the cell layer (Table 1). Addition of chloramphenicol after 1, 2 or $5 \mathrm{~h}$ of starvation resulted in attachment rates higher than at time zero $(\mathrm{p}<0.015)$, but still lower than on the 59 control without chloramphenicol $(p<0.015)$. The values are given as the number of surface-associated larvae. In control experiments, it was verified that neither the attachment of the larvae to control surfaces (Table 1) nor their development and metamorphosis were influenced by chloramphenicol (data not shown).
Table 1. Ciona intestinalis. Attachment of larvae on cell layers of Pseudomonas sp. strain S9 cells after inhibition of peripheral exopolysaccharide formation by chloramphenicol $(\mathrm{Cm})$ addition at different times during starvation (for further explanation see text). Controls correspond to attachment on a hydrophobic Petri dish with or without $\mathrm{Cm}$. Values represent the number of surface-associated larvae \pm SD and are calculated as described in Fig. 1

\begin{tabular}{lc}
\hline Time of $\mathrm{Cm}$ addition $(\mathrm{h})$ & Degree of attachment $(\%)$ \\
\hline 0 & $47.4 \pm 4.9$ \\
1 & $68.2 \pm 1.1$ \\
2 & $68.2 \pm 3.2$ \\
5 & $65.4 \pm 2.1$ \\
Control & $85.4 \pm 1.2$ \\
Control $+\mathrm{Cm}$ & $88.6 \pm 2.1$
\end{tabular}

\section{Cell layers of different thickness}

In order to vary the thickness of the thin S9 cell layers, the number of cells in the starvation suspensions was varied. The resulting thickness of the cell layers after $24 \mathrm{~h}$ of starvation was examined microscopically and ranged from a monolayer $\left(O D_{610}=0.1\right)$ to a multilayer $\left(O D_{610}=1.0\right)$. The multilayer displayed an irregular surface with strands of cells extending out into the solution. The formation of peripheral exopolysaccharide by S9 cells was only observed in the experiments involving cell suspensions with a low optical density of 0.1 and 0.5 .

Differences in degree of attachment between attached and surface-associated larvae were observed on all cell layers, independent of the thickness of the layer (Fig. 4) $(p<0.004)$. However, although the number of surface-associated larvae remained constant with increasing cell-layer thickness, the percentage of attached larvae decreased. The high number of trapped larvae on the multilayer surface was due to the irregular structure of the layer and to the strands of bacteria extending out into the solution, where the larvae were trapped. The supernatants of the starvation suspensions of differing densities were also tested for their influence on larval attachment. In all parallel tests, the degree of attachment was similar to that in the control (hydrophobic Petri dish; data not shown).

\section{Biofilms}

Growing biofilms consisting of the wild-type S9 or the mutant B29 were produced on hydrophobic plates and subsequently used in larval attachment experiments. Visible inspection of these growing bacterial 


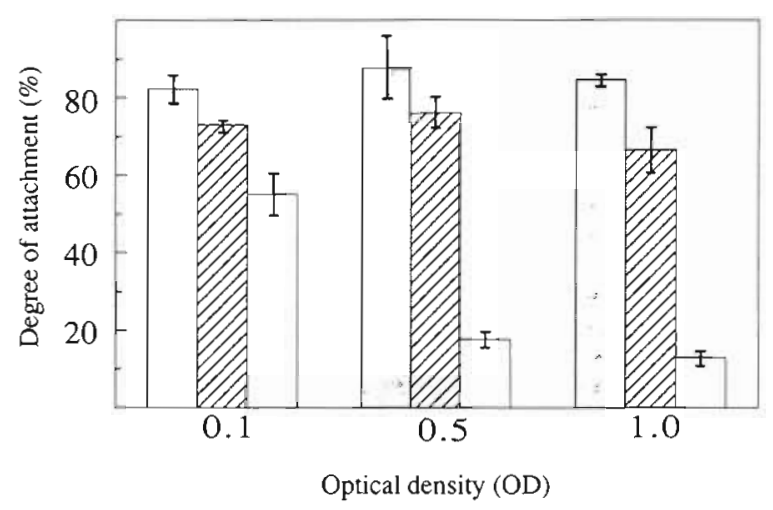

Fig. 4. Ciona intestinalis. Attachment of larvae on Pseudomonas sp. S9 cell layers of different thicknesses and hydrophobic Petri dishes in the presence of starvation supernatant derived from starvation suspensions of various optical densities. Three different cell-layer thicknesses, corresponding to bacterial-suspension optical densities $\left(\mathrm{OD}_{610}\right)$ of $0.1,0.5$ and 1.0, were included. Shaded bars: surface-associated (both attached and trapped) larvae on S9 cell layer; hatched bars: attached larvae on the control surface in the presence of supernatant; open bars: attached larvae on S9 cell layer. Values calculated as in Fig. 1

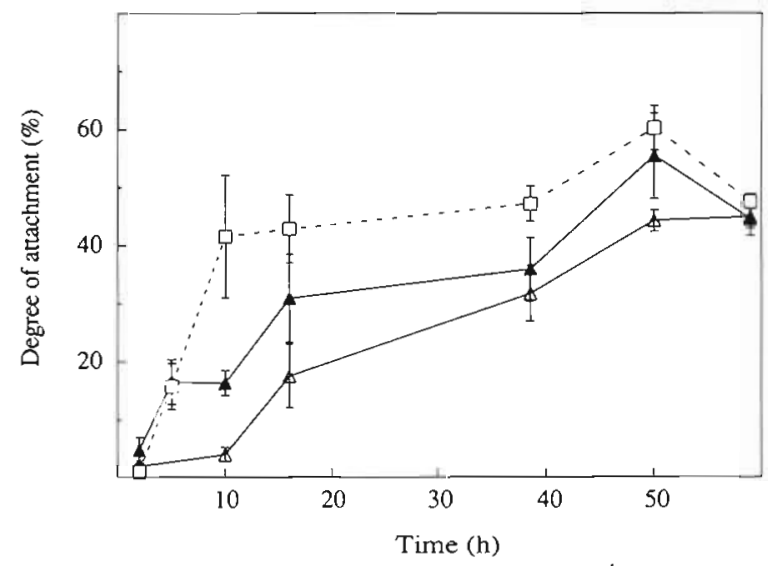

Fig. 5. Ciona intestinalis. Time course of larval attachment on growing biofilms of $(\boldsymbol{\Lambda}, \Delta)$ Pseudomonas sp. S9 or $(\mathbf{\omega}, \square)$ the mutant B29 strain. Filled and open symbols as in Fig. 3. Values calculated as in Fig. 1

films revealed limited slime formation on the wildtype film, while no slime was detected on the mutant film. The results of these biofilm experiments are presented in Fig. 5. After $15 \mathrm{~h}$ of incubation, and thereafter, the percentage of attached larvae was approximately the same as in the experiments with thin cell layers (Fig. 3). However, a considerably lower number of trapped larvae was observed on the growing S9 biofilm as compared to the thin cell layers, yielding relatively low values of surface-associated larvae during at least the first $38 \mathrm{~h}$ of incubation $(p<0.03)$. Furthermore, no trapped larvae were found on the biofilms consisting of the mutant B29, which only pro- duces the integral, capsule-like exopolysaccharide and not the peripheral form.

\section{DISCUSSION}

Tadpole larvae of Ciona intestinalis attach to surfaces by means of adhesive organs (Katz 1983), which belong to the simple coniform papillae type consisting of glandular and non-secretory cells (Cloney 1977a, b). The papillae secrete an adhesive (Cloney 1977a) which serves as glue. Prior to attachment, however, many ascidian larvae can recognize the characteristics of a surface (Torrence \& Cloney 1983); depending on surface conditions, the larvae can either attach or delay settlement until a more suitable substratum is found.

In addition to such active attachment, passive attachment to surfaces appears to be possible. The importance of slime layers and organic films for settlement has already been suggested (ZoBell 1938, Mihm et al. 1981). It is not known, however, whether the attachment to a slimy bacterial layer reflects passive trapping or instead an active process, e.g. mediated by lectinlike substances, as proposed for the polychaete Janua brasiliensis (Kirchman et al. 1982b).

We used the marine Pseudomonas sp. S9 as a model bacterium to examine the effect of extracellular polysaccharides that either form dense slime layers on surfaces or are found in capsular form on certain marine bacteria. The regulation of exopolysaccharide assembly and release by this strain has recently been studied (Wrangstadh et al. 1990), and the results allowed us to select conditions causing the strain to produce either integral, capsule-like, or peripheral exopolysaccharides. In short, Pseudomonas sp. S9 produces an integral exopolysaccharide during growth and the initial phase of exposure to energy and nutrient limitation. In addition, starvation induces the formation of a peripheral form of this exopolysaccharide, which extends away from the cell surface and is structurally different from the integral type, as seen by immuno-electron microscopy (Wrangstadh et al. 1990). Inhibition of this active starvation response by addition of chloramphenicol to prevent synthesis of starvation-specific proteins, or by use of grown dense biofilms, prevents formation of the peripheral exopolysaccharide.

The role of a self-produced poylmeric glue in the attachment of eggs of the ascidian Molgula pacifica has been demonstrated (Young et al. 1988). Eggs of Ciona intestinalis are sticky and non-buoyant in still water. Furthermore, it has been shown that eggs released in the field are embedded in a slime matrix which may be responsible for both the attachment of the eggs and the patchiness of their colonization (Svane \& Havenhand unpubl. data). In our test system with strain S9, we found 
that both the unfertilized and fertilized eggs, which were no longer embedded in the natural slime, attached at a significantly greater rate to bacterial cell layers that possessed slime. These findings indicate that fertilized eggs of $C$. intestinalis may also attach to surfaces, possibly allowing for protection against predation.

With the aid of sensory organs and motility, the hatched larvae can examine a surface and actively interact with substratum components. From the experiments with the exopolysaccharide-forming strain S9 it is obvious that the larvae can both actively attach to the cell layers or become trapped. The trapping effect of the exopolysaccharide was demonstrated by inhibition of peripheral-exopolysaccharide formation using chloramphenicol. When exopolysaccharides were not released, the number of surface-associated larvae decreased (Table 1), primarily due to a decrease in the number of trapped larvae (data not shown). The experiments with the transposon-generated peripheral exopolysaccharide, and release-deficient mutant strain B29 also resulted in a reduction in the number of trapped larvae (Fig. 3). These data support the hypothesis that slime layers of bacterial origin can be responsible for non-specific trapping of larvae. The same conclusion can be drawn from the biofilm experiments, where S9 produced only limited amounts of, and B29 produced no, peripheral exopolysaccharide. In fact, no trapped larvae were found on the B29 biofilm, while the number of trapped larvae on the $\mathrm{S} 9$ biofilm decreased significantly compared to that on the thin cell layer of S9.

From an ecological point of view, it is interesting that all trapped as well as attached larvae continued their development into juiveniles, and hence could contribute to population recruitment and colonization of new surfaces. Furthermore, our data provide detailed experimental evidence that the formation of a biofouling community with higher organisms may be greatly facilitated by the presence of bacterial exopolysaccharides.

Acknowledgements. We are grateful to Drs Dan Rittschof and Ib Svane for valuable discussions and to Olle Holgersson for help during the diving and sample collection. This work was supported by grants from the Bank of Sweden Tercentenary Foundation and the Swedish National Board of Technical Development.

\section{LITERATURE CITED}

Barnes, H. (1956). Surface roughness and the settlement of Balanus balanoides L. Arch. Soc. Zool. Botan. Fenn. 'Vanamo' 10: 164-168

Bryers, J. D., Characklis, W G. (1982). Processes governing primary biofilm formation. Biotechnol. Bioengng 24: 2451-2476
Butman, C. A., Grassle, J. P., Webb, C. M. (1988). Substrate choices made by marine larvae settling in still water and in flume flow. Nature, Lond. 333: 771-773

Cloney, R. A. (1977a). Larval adhesive organs and metamorphosis in ascidians. I. Fine structure of the everting papillae of Distaplia occidentalis. Cell Tissue Res. 183: $423-444$

Cloney, R. A. (1977b). Ascidian metamorphosis: review and analysis. In: Chia, F.-S., Rice, M. E. (eds.) Settlement and metamorphosis of marine invertebrate larvae. Elsevier, New York, p. 255-282

Crisp, D. J. (1974). Factors influencing the settlement of marine invertebrate larvae. In: Grant, P. T., Mackie, A. M. (eds.) Chemoreception in marine organisms. Academic Press, New York, p. 177-265

Eiben, R. (1976). Einfluß von Benetzungsspannung und Ionen auf die Substratbesiedlung und das Einsetzen der Metamorphose bei Bryozoenlarven (Bowerbankia gracilis). Mar. Biol. 37: 249-254

Katz, M. J. (1983). Comparative anatomy of the tunicate tadpole, Ciona intestinalis. Biol. Bull. mar. biol. Lab., Woods Hole 164: 1-27

Kirchmann, D. L., Graham, D. S., Reish, D., Mitchell, R (1982a). Bacteria induced settlement and metamorphosis of Janua (Dexiospira) brasiliensis Grube (Polychaete Spirorbidae). J. exp. mar. Biol. Ecol. 56: 153-163

Kirchmann, D. L., Graham, D. S., Reish, D., Mitchell, R. (1982b). Lectins may mediate in the settlement and metamorphosis of Janua (Dexiospira) brasiliensis (Grube) Mar Biol. Lett. 3: 1-12

Maki, J. S., Rittschof, D., Costlow, J. D., Mitchell, R. (1988) Inhibition of attachment of larval barnacles, Balanus amphitrite, by bacterial surface films. Mar. Biol. 97 199-206

Maki, J. S., Rittschof, D., Schmidt, A. R., Snyder, A. G. Mitchell, R. (1989). Factors controlling attachment of bryozoan larvae: a comparison of bacterial films and unfilmed surfaces. Biol. Bull. mar biol. Lab., Woods Hole 177 295-302

Mårdén, P., Tunlid, A., Malmcrona-Friberg, K., Odham, G., Kjelleberg, S. (1985). Physiological and morphological changes during short term starvation of marine bacterial isolates. Arch. Microbiol. 142: 326-332

Mihm, J. W., Banta, W. C., Loeb, G. I. (1981). Effects of adsorbed organic and primary fouling films on bryozoan settlement. J. exp. mar Biol. Ecol. 54: 167-179

Morse, D. E., Hooker, N., Jensen, L., Duncan, H. (1979) Induction of larval abalone settling and metamorphosis by gamma-aminobutyric acid and its congeners from crustose red algae II. Applications to cultivation, seed production and bioassays; principle causes of mortality and interference. Proc. Wld Maricult. Soc. 10: 81-91

Rittschof, D., Hoooper, I. R., Costlow, J. D. (1986a). Barnacle settlement inhibitors from sea pansies (Renilla reniformis). Bull. mar Sci. 39: 376-382

Rittschof, D., Maki, J., Mitchell, R., Costlow, J. D. (1986b). Ion and neuropharmacological studies of barnacle settlement. Neth. J. Sea Res. 20: 269-275

Torrence, S. A., Cloney, R. A. (1983). Ascidian larval nervous system primary sensory neurons in adhesive papllae. Zoomorphology 102: 111-124

Wrangstadh, M., Conway, P. L., Kjelleberg, S. (1986). The production and release of an extracellular polysaccharide during starvation of a marine Pseudomonas sp. and the effect thereof on adhesion. Arch. Microbiol. 145: 220-227

Wrangstadh, M., Szewzyk, U., Östling, J., Kjelleberg, S. (1990). Starvation-specific formation of a peripheral 
exopolysaccharide by a marine Pseudomonas sp. strain S9. Appl. environ. Microbiol. 56: 2065-2072

Young, C. M., Gowen, R. F., Dalby, J, Jr, Pennachetti, C. A., Gagliardi, D. (1988). Distributional consequences of adhesive eggs and anural development in the ascidian Molgula pacifica (Huntsman 1912). Biol. Bull. mar biol. Lab., Woods Hole 174: 39-46

This article was submitted to the editor
ZoBell, C. E. (1938). The sequence of events in the fouling of submerged surfaces. Official Digest Fed. Paint Varnish Prod. Clubs 178: 379-385

ZoBell, C. E., Allen, E. C. (1935). The significance of marine bacteria in the fouling of submerged surfaces. J. Bacteriol. 29: $239-251$

Manuscript first received: February 13, 1990

Revised version accepted: June 11, 1991 